\title{
MEASURING THE SOCIAL DiSCOUNT RATE UNDER UNCERTAINTY: A METHODOLOGY AND APPLICATION
}

\author{
SYED M. AHSAN \\ PANAGIOTIS TSIGARIS
}

CESIFO WORKING PAPER NO. 824

CATEgory 1: Public FinANCE

DECEMBER 2002 


\title{
MEASURING THE SOCIAL DiSCOUNT RATE UNDER UNCERTAINTY: A METHODOLOGY AND APPLICATION
}

\begin{abstract}
It is well recognised that the issue of the social rate of discount applies only to the gains from public investment that accrues to the public sector. When it comes to measurement, however, there is a problem: public investment in infrastructure and the like do not usually yield direct pecuniary returns to the public exchequer. Instead public capital may be plausibly argued to lead to increases in factor productivity in the private economy. This paper observes that government typically shares in the latter gains via the collection of tax revenues. Hence to the extent the risk discount rate should reflect the co-variability between the return from public investment and that of the market, we are led to measuring the risk premium implicit in various revenue flows. We apply the above methodology to the United States budget data for the period, 1950-2000, and show that the social risk premium is relatively small vis-à-vis the market. Consequently, the use of the risk free rate as the correct risk discount rate for public sector investment would involve only a minor error. The intuition here is that the portfolio of assets embedded in the state's revenue claims provides additional diversification than is available through financial markets. Therefore, even investors holding well-diversified stock portfolios may legitimately view claims on state revenue as vehicles for further risk shifting.
\end{abstract}

Keywords: public discount rate, risk premium, aggregate risks, correlated risks, public investment.

JEL Classification: D8, E3, G1, H4, H5, H6.

Syed M. Ahsan

Department of Economics

Concordia University

1455 Boul. De Maisonneuve Ouest

Montreal, Qc

Canada H3G $1 M 8$

ahsansm@vax2.concordia.ca
Panagiotis Tsigaris

Department of Economics and

Finance

University College of the Cariboo

Kamloops, $B C$

Canada V2C $5 N 3$ 


\section{Measuring the Social Discount Rate under Uncertainty:}

\section{A Methodology and Application ${ }^{1}$}

\section{Introduction}

What should be the appropriate risk discount rate for the public sector investment, say in infrastructure? The risk-free rate or the rate faced by the corporate sector? There are several distinct answers in the literature. Hirshleifer $(1964,1966)$ and Sandmo (1972) argue in favour of one rate for both sectors, where the actual rate would depend on the risk class the investment belongs to; "for each type of public investment, it is possible to find a private industry such that returns are highly correlated" (Sandmo, 1972, p287)2. In a critique of the Hirshleifer position, Samuelson (1964) and Vickrey (1964), look upon the government as primarily a device for mutual reinsurance. To quote Samuelson, "...General Motors can borrow at a lower rate than American Motors because it is a pooler of more independent risks... The same holds for We, Inc., which is a better pooler than even GM..." (p96). Both Samuelson (1964) and Vickrey (1964) argue for the risk free rate. The return on human capital risk, which is believed to be largely idiosyncratic, is often pointed out as a case in point [Eaton and Rosen, (1980a, b) and Varian (1980)]. Consequently, by taxing labour income the government may pool across the latter risk, and improve on the market allocation. Thus, as we argue below, the overall market value of revenue may well depend on the mix of available revenue sources.

Arrow-Lind (1970) also recommended the risk-free rate. They however distinguish between two cases, both related to the framework chosen by Hirshleifer and further elaborated upon by Sandmo. First, Arrow-Lind point out that Hirshleifer is mostly correct in the sense that even if the government is able to pool better, cheap public borrowing deprives the private sector of investments, which are of greater market value (crowding out). However, if the marginal project had returns that did not correlate with past project returns (i.e., the existing portfolio), any investor (public or private) is entitled to the risk-free rate in a perfect markets setting. Thus the Arrow-Lind focus happens to be in a scenario where the public sector investment yields benefits, which do not correlate well with the current portfolio of investments, public or private. ${ }^{3}$ The second case proposed by Arrow-Lind is based on the risk-spreading concept. To the extent the benefits of public investment accrue to the public sector, which is also paid for by the government (say, via taxes), "a public investment can be considered as an investment in which each individual taxpayer has a very small share" (p370).

\footnotetext{
${ }^{1}$ Earlier versions of the paper have been presented at economics faculty workshops at the Chinese University of Hong Kong, Economic Policy Research Unit (EPRU, Copenhagen), Helsinki, Frankfurt, Korean Institute of Public Finance, New Hampshire, Norwegian Business School, Uppsala and Wuerzburg. The authors gratefully acknowledge the hospitality at EPRU, and the helpful comments made by seminar participants, especially, Jonas Agell, Craig Brett, Niels Blomgren-Hansen, Katherine Cuff, Gordon Fisher, Jim Hines, Mike Hoy, Erkki Koskela, Andy Kwan, Carla Marchese, Soeren Nielsen, Agnar Sandmo, Hans-Werner Sinn and Jay Wilson.

${ }^{2}$ Similarly, in later writings concerns have been voiced that tax revenue risks were just as costly for the state to bear as for private agents [Gordon (1985) and Hamilton (1987)]. Bulow and Summers (1984) indeed have gone the farthest, and have argued that corporate tax revenue resembles capital gains in terms of the underlying risk, and correspondingly, relying on this revenue, "..[Government] can only finance programs whose budgets may have a certainty equivalent of zero", p21).

${ }^{3}$ Pauly (1970) however believed, much along the Hirshleifer-Sandmo position, that there was little reason to suppose that public investment would be any less correlated with the aggregate risk than private investment of "equal term" (p196).
} 
Consequently, "the government distributes the risk associated with any investment among a very large number of people.... It is the risk-spreading aspect that is essential to the result" (p366). Here again the derivation of the risk free discount rate requires the independence assumption. To sum up then, the second Arrow-Lind result in support of the risk free rate as the social discount rate is based on the state being able to apportion the risk of each uncorrelated project among a large number of risk sharers. $^{4}$

Importantly, one common hypothesis that is crucial for the correctness of the risk free rate as the social discount rate is the mutual independence of investment returns. How plausible is this? ArrowLind themselves raised the concern: "if there is positive correlation between the returns of an investment and other components of national income, the question remains whether this correlation is so high as to invalidate the previous result" (p373). Sandmo also wondered on the relevance of an ideal stock market (for each state-time contingencies) and real world markets: "How close the approximation may be is of course an empirical question..."(p 296).

The present paper develops a framework to measure the closeness of the returns from public investment with the other components of GDP, and thereby provide an empirical answer to the above debate. We note that neither group of authors actually dwells on how one may be able to empirically verify the issue at hand. Clearly one would first require an observable equivalent of the benefits of public investment. Arrow and Lind make the important point that benefits of public investment may in general accrue both to private agents (e.g., farmers gaining from public investment in irrigation) and to the government. The former would be valued by private individuals "with respect to both time and risk in accordance with the preferences of the individuals to whom they accrue" (p377). The social discount rate therefore applies only to the portion of benefits that accrues to the government. In their exact formulation, however, the government actually "captures all benefits and pay all costs" (p370), since private individuals who gain from the investment are presumed to pass on the benefit to the treasury in entirety.

Our first observation is that the above description hints at how one may go about measuring the public gains from public investment. The most direct manner we know how "the beneficiaries pay to the government an amount equal to the benefit received" is via the institution of taxation (whether construed as Lindahl prices or otherwise). We suggest in what follows that public investment (say, in education, health, and infrastructure) leads to gains in the productivity of labour and capital. ${ }^{5}$ Given a well functioning tax system, such private sector gains would lead to higher government revenue on account of augmented wages, profits, and value of transactions. Thus tax revenue would serve as the observational equivalent of the public gains. Evidently not all revenue (say from the personal income tax) arises out of enhanced productivity due to investments in public education and health; but the procedure we propose use tax revenue flows only to measure its volatility relative to GDP, as stipulated by the writers described above. ${ }^{6}$

\footnotetext{
${ }^{4}$ There is another important distinction between the two results discussed by Arrow-Lind. Note that their first result is cast in the same format as the Hirshleifer-Sandmo model of perfect capital markets, where household portfolios are fully diversified. The former authors show that the mere qualification of uncorrelated projects alters the conclusion. The second Arrow-Lind result does not require that private capital markets are perfect, and thus individuals may not diversify fully. Hence there arises the significance of each bearing very small risks.

${ }^{5}$ Public investment in our context is very much of the public good variety, where there is a clear market failure. Private markets are otherwise taken as complete allowing individuals to diversify fully.

${ }^{6}$ Hence the level of revenues are not central to the methods developed here, only the variability.
} 
We conceive a framework where public investment is bond financed, while the debt charges are covered by taxation, which only differs marginally from that in Arrow-Lind. In the latter, financing is done via taxation, and in the event of positive (negative) net gains taxes are reduced (increased) from the planned level. In our framework, the discount rate is derived implicitly as the rate that value-maximizing investors are willing to pay for government bonds that are earmarked to be serviced by future taxation.

One procedure to estimate the market risk premium of the revenue flows would be to identify, à la Hirshleifer-Sandmo, a publicly traded company that has earnings that matches perfectly the revenue flows in question. The risk premium implicit in the latter would then exactly equal what is applicable to the firm's equity, where the risk class of the publicly traded company can be identified using assetpricing models. Since this is a tedious trial and error procedure, we propose an indirect method to identify the risk class of the public flows. Our approach would be capable of determining the "market" risk premium of public revenue flows even though we do not observe securities that have exclusive claims on the former. ${ }^{7}$

To illustrate further, consider the corporate income tax (CIT). The total CIT base is clearly the sum of pre-tax net income of all firms. One may therefore interpret the tax base as a stream of net revenue flows arising from a portfolio of corporate equities, where care has been taken to add up each component by its relative weight in the total. Given a particular tax schedule, in this instance the rate of tax, and for simplicity allowing full loss-offsets, the tax revenue would therefore embody the same risk characteristics that afflict corporate earnings. Further note that, assuming economic depreciation in the tax schedule, the net income of a firm becomes the conceptually correct measure of its return on capital, while changes in its level essentially constitute the accrued capital gains on the firm's equity. Were this source to be the sole revenue claim of a government, and it wished to borrow, lenders could logically demand an expected rate of return that reflects the riskiness of the de facto collateral asset, namely the CIT base. Claims on future corporate tax revenue may therefore be seen to be formally similar to claims on corporate earnings. ${ }^{8}$

Turning to other taxes, one important distinction would be that here even the underlying portfolios do not be trade in any actual market unlike the CIT base. ${ }^{9}$ An example is that of the personal income tax (PIT) revenue. Here the tax base consists of returns to human capital, individual capital and entrepreneurial income. Again the taxable part is in the nature of an income net of direct costs of earning income, and thus has the interpretation of a return on the totality of human, entrepreneurial and physical capital stock attributable to the personal sector of the economy. The latter capital is mostly untraded in actual markets, and hence it is conceptually important to develop an appropriate measure of the systematic risk implicit in such incomes. The remaining taxes (notably, payroll, domestic goods and services, and foreign trade) may be similarly motivated.

The procedure we develop to derive the risk premium implicit in tax revenue flows proceeds as follows. Recall that we interpret tax revenues as the return on public investment, and thus revenues serve as surrogate "return" on assets (i.e., bonds) issued to finance the investment in the first place. We compare the behaviour of the latter return with the growth rate of earnings of

\footnotetext{
7 This methodology can be applied to any non-traded asset such as the risk premium implicit in various human capital investments as well as evaluating small businesses.

${ }^{8}$ See also Bulow and Summers (1984).

${ }^{9}$ We abstract from the fact that many firms organised as corporate entities merely for tax purposes are closely held, and hence do not trade.
} 
another well-known asset, namely the market portfolio (say as measured by the S\&P500 index), and in particular examine the sensitivity of the relative earnings growth on the two assets with a common aggregate factor, that of GDP growth. The differenced series (namely, growth rate of tax revenue less the earnings growth on the market portfolio) should be independent of aggregate economic conditions if tax revenues are as risky as the stock market. This independence would imply that tax revenue commands a risk premium that is of the same magnitude as the market portfolio. In the case where the difference in the mutual growth rates is positively (negatively) correlated with the growth of the economy then we argue that the risk premium for the tax revenue backed security could be higher (lower) than that applicable to the market portfolio.

The approach cited above has interesting implications for several related issues in public economics, namely the choice of the social discount rate, the borrowing capacity of state and local authorities, the size of sustainable debt, programs financed by earmarked budgeting, and more broadly, on the identification of risk premium implicit in any non-traded asset. ${ }^{10}$ The principle focus of this paper is on estimating the social discount rate. However, turning to the size of debt, were the BulowSummers' suggestion that CIT revenues were just as risky as the market portfolio to apply to overall revenue, admittedly an extreme hypothesis, no positive debt would be sustainable. More generally, however, one can go on to model the limit to debt size under steady state properties of revenue flows. The implications for ear-marking are rather evident; should the source of finance be very risky, not only would the program output have an unacceptable level of volatility, borrowing against future revenue (from the same source) would appear unwise due to its low market value. Consequently, ear-marking could be practised only in limited instances where, either, the revenue source had little systematic risk, or, by coincidence, both demand for the service and revenue claims were near perfectly correlated.

The balance of the paper proceeds as follows. In section 2 we present the basic methodology of evaluating the risk premium. Next we apply the above methodology to the case of tax revenue flows, and obtain the estimated risk premium implicit in these flows (section 3). Implications of the analysis for the public discount rate are reviewed in section 4, where we find that the risk discount rate is even lower for a data set that excludes the Korean War period. Consequently there arises the possibility of a "peace dividend", and we go on to discuss the dividend for the overall size of US public debt. Next we offer a few concluding remarks in section 5. Some background results are collected in the form of a brief appendix.

\section{Methodology for Valuing the (Implicit) Risk Premium}

We have argued above that tax revenue (especially from personal and corporate source incomes) may, at least in a qualitative sense, be taken as the component of the gains from public investment that accrues to the public sector. Consequently the discount rate relevant for evaluating such future gains, that is to say for the public investment decisions in the first place, should reflect the risk inherent in the future returns to physical and human capital. We are thus led to the issue of measuring the risk premium implicit in the stochastic behaviour of revenue collections.

In order to model the public discount rate as construed above, one needs to conceptualise terms such as the current market price of future revenue entitlement. To motivate the discussion, consider a government willing to currently borrow the market value of its future revenue claims (due $k$-periods

\footnotetext{
${ }^{10}$ See Shiller (1993)
} 
from now) ${ }^{11}$ In the process, we assume that the purchasers of government bonds hold a diversified portfolio of assets, and consequently, when valuing the risk embedded in the bond, they would naturally evaluate the riskiness of future tax revenue. Once a particular public revenue flow has been assigned a "price", one is led to the idea of the return that the holder of the entitlement would earn from such a hypothetical debt instrument. Rational portfolio investors would therefore be willing to lend to the state at time- $t$ an expected amount $P_{t}$ in exchange of the promise of the expected stochastic flow $R_{t+k}, k$-periods later:

$$
P_{t}=E_{t} \sum_{k=0}^{\infty} \frac{R_{t+k}}{(1+\delta)^{k+1}}
$$

In the expression above, $P_{t}$ may be interpreted as the current "market price" of a claim on the future expected revenue stream ("dividends"), $\left(R_{t+k}\right)$, and $\delta$ is the risk discount rate. ${ }^{12}$

The appropriate discount rate which explicitly adjusts for the riskiness of the revenue stream may be given by the security market equilibrium condition which states that the expected return on an investment equals the sum of the risk free rate and a risk premium term that is proportional to the excess return on the market portfolio:

$$
\delta=E\left(r_{t}\right)=r_{f t}+b\left(E\left(r_{m t}\right)-r_{f t}\right) .
$$

In the expression above $r_{t}$ denotes the current "real rate of return" on the security with exclusive claims on tax revenue flow $\left(R_{t+k}\right)$, while $r_{f t}$ and $r_{m t}$ are, respectively, the risk free rate and the total return on the market portfolio. ${ }^{13}$ The $b$-coefficient, or beta, is the measure of the underlying portfolio risk, and is defined in the usual way, namely, $b=\left\{\operatorname{cov}\left(r_{t}, r_{m t}\right) / \sigma_{m}^{2}\right\}$. The market risk premium therefore depends on the co-variability of the return on the revenue-backed asset in question with the market portfolio. The risk discount rate is thus decomposable into two components. ${ }^{14}$

The argument thus far is analogous to the standard "capital asset pricing model" (CAPM) developed by Lintner (1964), Mossin (1966) and Sharpe (1964). Indeed the conceptual methods advanced by Hirshleifer (1964) and Sandmo (1971) for deriving the risk discount rate can be viewed as being consistent with the former. If the returns from a particular investment project (tax revenues in the present case) were actually independent of any systematic risk, the risk premium would be zero

\footnotetext{
${ }^{11}$ In effect the above procedure does describe the model behind the determination of the government (long-term) bond rate. Therefore the extent to which the observed bond rate would differ from that predicted by the model would depend on the closeness of the model to the actual investment environment or to the type of tax revenue category. We shall have occasion to revisit this issue later in the paper.

${ }^{12}$ In the finance literature this basic valuation formula has been disputed on grounds that asset prices display excessive volatility relative to the anticipated stream of future dividends (Shiller, 1981).

${ }^{13}$ An alternative approach to the evaluation of risky tax revenue flows is to compute the certainty equivalent of the risky tax revenue and then use the risk free rate to discount the certainty equivalent future flows. See Ahsan and Tsigaris (1998).

${ }^{14}$ The above reasoning runs parallel to that advanced by Pauly (1970), who argued that public investment was, much like private ones, also subject to the systematic risk embedded in the economy. The latter risk may drive the actual yield on a public investment to zero. Thus even though bondholders expect and do receive a fixed coupon, "public investment implies assumption by taxpayers of the social risk associated with that investment" (p196). The formalisation being proposed here illustrates the principle that "the cost of public investment is not just the interest cost of funds to the government but also includes the assumption of social risk by risk-averting taxpayers" (p197). In our context, risk premium described in (2.2) is the social risk à la Pauly, while the risk free rate serves as the marginal rate of private time preference. The risk discount rate is therefore the sum of these two elements.
} 
(as the market beta would be zero). In such a case, the appropriate discount rate would be the rate of time preference, namely $\delta=r_{f t}$. An example may be the wage tax revenue. It is plausible that in a diversified economy such revenue would become riskless in the aggregate. ${ }^{15}$ At the other extreme, Hirshleifer and Sandmo highlight a result where public investment leads to a pattern of revenue that perfectly covaries with the market portfolio (i.e., a beta of unity). The public discount rate, therefore, coincides with the rate applicable to private projects with the identical market risk premium. In such a world, the public sector must emulate private firms in order to achieve allocative efficiency. ${ }^{16}$

The CAPM methods can be used to empirically obtain the risk premium associated with securities that actually trade in the market. In our case, these methods are however not applicable since the beta coefficient cannot be computed due to the non-existence of data on asset prices. Below we describe an alternative methodology for measuring the implicit risk premium that is general enough to be applicable to any risky asset, including those non-traded.

We proceed by modelling the dynamic behaviour of the price to earnings ratio (PER) in financial markets. We assume that the price behaviour of a traded asset- $i$ at time-t, $P_{i t}$, and the earnings per share, $I_{i t}$, as governed by the following stationary process: $\left(\frac{P}{I}\right)_{i t}=A\left(\left(\frac{P}{I}\right)_{i t-1}\right)^{c_{1}} e^{u_{i t}}$. In logarithmic form we have:

$$
p_{i t}=c_{0}+c_{1} p_{i t-1}+u_{i t}
$$

where $p_{i t}=\ln \left(\frac{P}{I}\right)_{i t}, c_{0}=\ln A$, and $0<c_{1}<1$

for a stationary process, and $u_{i t}$ is a random error term. The assumption of stationarity guarantees that the price to earnings ratio is mean reverting. The long run steady state (or, unconditional mean) of the logarithm of the price to earnings ratio is: $E\left\{p_{i t}\right\}=\frac{c_{0}}{1-c_{1}}$. In the event of a shock, the price to earnings ratio will deviate from its long run level, as would be the case with the conditional expectations as Figure 2.1: The Price Earnings Ratio: 1871-1999 well. For example, a positive shock

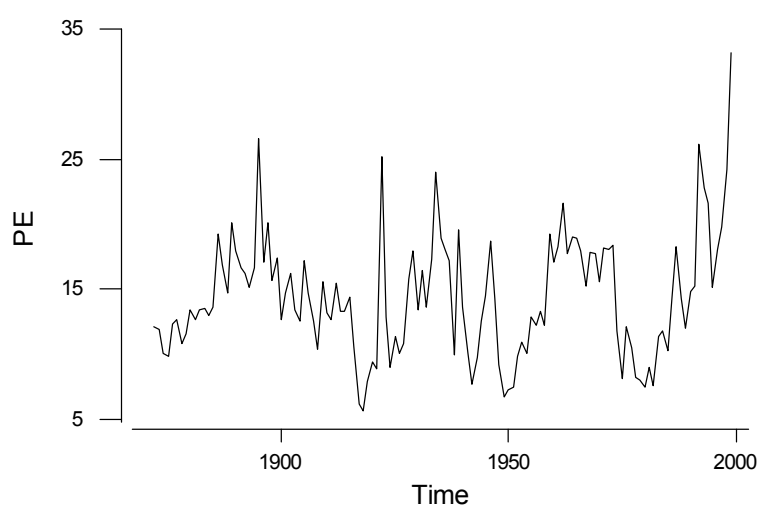
will result in the PER to increase above its steady state value. Investors will form conditional

\footnotetext{
${ }^{15}$ The argument here is, much in the spirit of Samuelson and Vickrey, that the risk is totally idiosyncratic in the aggregate since the government can effectively pool across individual differences.

${ }^{16}$ If one allows sharing of risks (say via public debt) across generations, who are not all simultaneously alive, Ahsan and Tsigaris (1998) have shown that the social risk premium would be strictly less than the market premium even when tax revenues were as risky as the market.
} 
expectations accordingly. Assuming the PER to be a stationary process, they will expect it to drop in the future towards its long run equilibrium value. Thus in the long run the price to earnings ratio will move back to the unconditional mean provided that there are no further shocks. Evidently the price to earnings ratio will fall if either the price falls and/or earnings increase until the long run equilibrium is achieved once again. Figure 2.1 shows the historical price to earnings ratio for the Standard and Poor 500 index. $^{17}$

The estimation of (2.3) is shown below as:

$$
\begin{aligned}
& \ln (\hat{P} / I)_{t}=0.78377+0.70282 \ln (P / I)_{t-1} \\
& t-\text { stats } \quad 4.4255 \quad 10.6735 \\
& \mathrm{~s}=0.239, \text { Adj. } \mathrm{R}-\mathrm{Sq}=0.461
\end{aligned}
$$

In order to examine whether the price to earnings ratio is stationary we applied the Dickey-Fuller (1979) test by estimating (2.3) again as follows: ${ }^{18} \Delta \ln (P / I)_{i t}=a_{0 i}+\gamma_{1 i} \ln (P / I)_{i t-1}+\xi_{i t}$. We tested the significance of the estimated coefficient for $\gamma_{1 i}$. The estimator is -0.2972 , and has a $t$ value of -4.41 . We are therefore able to reject the null hypothesis at the $1 \%$ level of significance, and conclude that the price to earnings ratio is both stationary and mean reverting. ${ }^{19}$ The PER seems to be reverting to its historical average value of 14 . The above exercise suggests that along a steady state the growth rate of prices should equal the growth rate of earnings per share. Outside a steady state the price to earnings ratio would of course be changing depending Figure 2.2: S\&P Index and Earnings Growth: 1871-1999

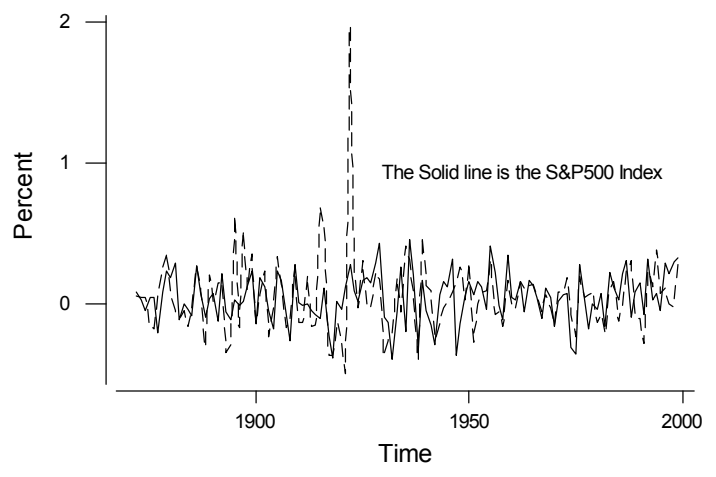
on the shock or its conditional expectations. Thus in a steady state we have:

$$
E\left\{g\left(P_{i t}\right)\right\}=E\left\{g\left(I_{i t}\right)\right\},
$$

where $g(x)$ denotes the growth rate of any variable- $x$, a notational feature that we shall maintain throughout. Indeed using Shiller's historical annual series from 1871-1999, we obtain the result that confirms the equality of the unconditional means of the two series. The annual average percentage change in the S\&P500 index adjusted for inflation during this period of time was $4.39 \%$ with a standard deviation of $17.6 \%$, while the annual growth rate of the earnings per share was $5.13 \%$ with a standard deviation of $27.7 \%$. Thus the difference in sample means is -0.0074 with the t-statistics of -0.26 . Thus we cannot reject the hypothesis that the unconditional means are equal in the long run. Figure 2.1 indicates the pattern of the growth rates.

\footnotetext{
${ }^{17}$ The data used are from Shiller's homepage: http://www.econ.yale.edu/ shiller/.

${ }^{18}$ No lagged terms were necessary since the residuals from this regression behaved appropriately. The results are the same as the one depicted in (2.4) except that the coefficient $\gamma=\left(c_{1}-1\right)$.

${ }^{19}$ The critical value from the Dickey Fuller table is -3.42 .
} 
Let us now introduce a second asset-j, which may well be non-traded. In the latter event, though there will not be any observable price to earnings ratio, we shall argue that the notion of imputed price to earnings ratio (IPER) can be used to determine risk. The minimal condition that will be required here is that the IPER be defined, and that it be stationary. While we require the IPER for asset-j be governed by a stationary process in the manner of (2.3) above, its unconditional mean may well be different from that of asset-i. ${ }^{20}$ However, in such an event, asset-j will also satisfy the long run condition discussed above, namely $E\left\{g\left(P_{j t}\right)\right\}=E\left\{g\left(I_{j t}\right)\right\}$ much as if it were actually traded in the market. ${ }^{21}$ This implies that in the long run the following is also true:

$$
E\left\{g\left(P_{i t}\right)\right\}-E\left\{g\left(P_{j t}\right)\right\}=E\left\{g\left(I_{i t}\right)\right\}-E\left\{g\left(I_{j t}\right)\right\}
$$

Furthermore, note that the expected return from any security is not merely the price appreciation component but also includes dividend yields. The expected total return from an investment-k is given therefore by the sum: $E\left(r_{k t}\right)=E\left(g\left(P_{k t}\right)\right)+E\left(d_{k t}\right)$.

Using Shiller's series (1871-1999), the historical average dividend yield over this long period of time comes to $3.2 \%$ (when adjusted for inflation) with a standard deviation equal to $8.7 \% .^{22}$ The real rate of interest as proxied by the annual yield on the holding of commercial paper has been around the same value $(3.3 \%)$ with the same standard deviation. ${ }^{23}$ The difference in the average yields is statistically insignificant. Figure 2.3 provides the historical the pattern of the two series.

Therefore we adjust (2.6) as follows:

$$
E\left(r_{i t}\right)-E\left(r_{j t}\right)=\left(E\left\{g\left(I_{i t}\right)\right\}+E\left(d_{i t}\right)\right)-\left(E\left\{g\left(I_{j t}\right)\right\}+E\left(d_{j t}\right)\right)
$$

Next step in the process is to find economic determinants of the expected growth of the rate of return on assets, earnings and dividends. As already stipulated above, for the overall rate of return on asset-k we use the security market line: $E\left(r_{k t}\right)=r_{f t}+b_{k}\left(E\left(r_{m t}\right)-r_{f t}\right)$, where the factor of proportionality is the well-known beta coefficient, namely, $b_{k}=\frac{\operatorname{cov}\left(r_{k t}, r_{m t}\right)}{\operatorname{var}\left(r_{m t}\right)}$. Substituting the

\footnotetext{
${ }^{20}$ The parameters $\mathrm{c}_{0}$ and $\mathrm{c}_{1}$ could differ relative to the market's price earnings autoregressive process.

${ }^{21}$ Note that the growth rates for two different assets could also differ along a steady state.

${ }^{22}$ The nominal dividend yield averages 4.8 with a standard deviation of only $1.3 \%$. Thus all the additional volatility arises from the PPI inflation adjustment.

${ }^{23}$ The Pearson correlation between the two series was equal to 0.93 . This implies that the dividend yield behaves similarly to the real interest rate, and the former may therefore be considered a relatively safe return on investment.
} 
market equilibrium condition for the determinant of the rate of return of assets into equation (2.7), we get the following expression: ${ }^{24}$

$$
\left(b_{i}-b_{j}\right)\left(E\left(r_{m t}\right)-r_{f t}\right)=\left(E\left(g\left(I_{i t}\right)\right)+E\left(d_{i t}\right)\right)-\left(E\left(g\left(I_{j t}\right)\right)+E\left(d_{j t}\right)\right)
$$

If we now allow one of the assets to represent the market portfolio, say asset-i, (i.e., let $i=m$ ), we know that its beta is unity, and hence the above comparison simplifies as follows: ${ }^{25}$

$$
b_{j}=1+\frac{\left(E\left\{g\left(I_{j t}\right)\right\}+E\left(d_{j t}\right)-\left(E\left\{g\left(I_{m t}\right)\right\}+E\left(d_{m t}\right)\right)\right)}{\left(E\left(r_{m t}\right)-r_{f t}\right)}
$$

Since any earnings growth (inclusive of dividends) contains systematic risk we need to obtain the sensitivity factor with respect to the state of the economy. We hypothesise that the actual growth rate of earnings plus dividend yields for any asset- $k$ is sensitive to the rate of growth of GDP, $Y$, (or, for that matter, any common aggregate indicator embodying systematic risk) as specified below: $g\left(I_{k t}\right)+d_{k t}=a_{1 k} g\left(Y_{t}\right)+e_{k t}$. Here $e_{k t}$ denotes a zero mean idiosyncratic, but investment specific shock, while $a_{l k}(k=j, m)$ is the sensitivity coefficient for the $k$-th asset. Differencing, we therefore obtain:

$$
\left(g\left(I_{j t}\right)+d_{j t}\right)-\left(g\left(I_{m t}\right)+d_{m t}\right)=\left(a_{1 j}-a_{1 m}\right) g\left(Y_{t}\right)+w_{j t}
$$

The above formulation indicates that the growth rate of the economy, the common factor, is a determinant of the differences in the growth rate (inclusive of dividends, if any) of earnings on asset-j vis-à-vis that of the market portfolio. Hence if it turns out that there is no dependence between the relative earnings on these assets and the evolution of the state of the economy, we may then claim that the two assets belong to the same risk class.

Continuing the above line of reasoning, we note that if the coefficient of output growth in (2.10) were negative (positive), asset- $j$ would be interpreted as less (more) risky than the market. Notice that the imputed earnings of a non-traded asset plus its dividend yield is expected to grow more in the long run than the corresponding flows of the market portfolio if and only if the GDP sensitivity of the former is greater than that of the market. The estimated coefficient in (2.10) is obtained from short run movements in the variables and is given as follows:

$$
\left(a_{1 j}-a_{1 m}\right)=\frac{\operatorname{cov}\left\{\left(g\left(I_{j t}\right)+d_{i t}\right)-\left(g\left(I_{m t}\right)+d_{m t}\right), g\left(Y_{t}\right)\right\}}{\operatorname{var}\left\{g\left(Y_{t}\right)\right\}}
$$

This measures the sensitivity of the differences in growth rate of the earnings flow to output fluctuations. Substitution of the expected value of (2.10) into (2.9) yields: ${ }^{26}$

$$
b_{j}=1+\frac{\left(a_{1 j}-a_{1 m}\right) E\{g(Y)\}}{\left(E\left(r_{m t}\right)-r_{f t}\right)}
$$

\footnotetext{
${ }^{24}$ In effect we assume that the non-traded asset would be priced according to the security market line.

${ }^{25}$ We may also use the above framework to compare one non-traded asset with another, but in that case we cannot say anything about the absolute value of its risk premium only relative. The comparison with a traded asset's riskiness allows us to obtain explicit values for the riskiness of the non-traded asset.

${ }^{26}$ Note that in (2.11) we have denoted the long run expected output (i.e., the trend rate) without a time subscript. This convention will be followed throughout the rest of the paper.
} 
Notice that for $a_{1 j}=a_{1 m}$, we get $b_{j}=1$ as argued above. Otherwise, if $a_{1 j}$ is smaller (larger) than $a_{1 m}$, clearly the beta will then be smaller (greater) than unity.

The final step in the analysis is to find out how sensitive is the market excess return to the growth rate of the economy. Following (2.10), we model the current market risk premium and GDP as follows:

$$
\left(r_{m t}-r_{f t}\right)=\lambda_{m} g\left(Y_{t+1}\right)+e_{j t}
$$

where the coefficient $\lambda_{m}$ measures the "beta" sensitivity of the current market premium to the future growth rate of GDP. ${ }^{27}$ Hence in expectation terms, the market risk premium in the long run is proportional to the growth rate of output as follows: $E\left(r_{m t}\right)-r_{f t}=\lambda_{m} E\{g(Y)\}$. The estimated coefficient from (2.12), obtained from short-run data, is given by: $\lambda_{m}=\frac{\operatorname{cov}\left\{r_{m t}-r_{f t}, g\left(Y_{t+1}\right)\right\}}{\operatorname{var}\left\{g\left(Y_{t+1}\right)\right\}}$. This latter coefficient measures the sensitivity of the market risk premium to future economic fluctuations. Therefore combining (2.11) and (2.12), along a steady state, we get:

$$
b_{j}=1+\frac{a_{1 j}-a_{1 m}}{\lambda_{m}}
$$

The beta of any security may therefore be interpreted as equalling the beta of the market portfolio (which is unity) plus a factor that is determined by the ratio of the relative sensitivities of the differential earnings flow on the two assets and the market excess return to output growth. In the special case where $\lambda_{m}=a_{1 m}$, we get an even simpler expression namely that the beta coefficient of the non-traded asset is proportional to the sensitivity factors for the two assets: $b_{j}=\frac{a_{1 i}}{a_{1 m}}$. The interpretation of the required condition is simply that the covariance between market risk premium and output growth be the same as the covariance between the total return on the market portfolio (inclusive of dividend growth) and output growth.

The above analysis therefore illustrates a procedure by which we may empirically estimate the beta coefficient, and thus the risk premium, for a non-traded asset. From (2.13) it is clear that one merely needs to estimate three parameters, namely $a_{1 j}, a_{1 m}$ and $\lambda_{m}$, of which only the first utilise information on the non-traded asset- $j$. Indeed estimating the first of these parameters requires long period data on the imputed rate of return on the asset, and the hypotheses that the dynamic behaviour of the latter was similar to that of a market portfolio. To the extent these assumptions may be taken as plausible ex post would depend on the nature of the quantitative results and their accordance with intuition, issues to which we shall now turn our attention.

27 Equation (2.12) may be viewed as embodying the hypothesis that the stock market is a leading indicator of cyclical shocks. Alternatively, writing the output term as a deviation from the trend level, and suitably adding a constant term equalling the latter, one would obtain a single factor arbitrage pricing theory interpretation of the ERM behaviour as developed by Ross (1976), and later expanded by Chen, Roll and Ross (1986) and Burmeister and Wall (1986). 


\section{Systematic Risk in Revenue Flows}

In this section, we apply the above methodology to estimate the risk premium implicit in tax revenue flows for the period $1950-2000 .{ }^{28}$ Here we shall interpret the various revenue categories- $j$ as examples of implicit returns on the corresponding asset- $j$, which will serve as the second asset as analytically modelled above. We start with an examination of the sensitivity of revenue growth to GDP behaviour.

3.1 Revenue-GDP Behaviour: We may generally write the tax revenue function as

$$
R_{j t}=F\left(\tau_{t}\right) B_{t}\left(F\left(\tau_{t}\right), Y_{t}\right),
$$

where $R_{j t}$ is the real tax revenue received by the government from the $\mathrm{j}$-th source, while $F\left(\tau_{t}\right)$ is the tax schedule, and $B_{t}\left(F(\tau), Y_{t}\right)$ denotes the tax base. We conceive the long run output as given by a function, $Y=Y(N, K, T)$, where the independent variables are population $(N)$, stock of capital $(K)$, technology $(T){ }^{29}$ Given (3.1), we hypothesise that the tax revenue is a stable exponential function of GDP, $R_{j t}=A Y_{t}^{\gamma_{j}} e^{\xi_{j t}}$, where $\xi_{j t}$ is a random error term with mean zero. It will be convenient to express the above in the log-linear form:

$$
\ln R_{j t}=\gamma_{0 j}+\gamma_{1 j} \ln Y_{t}+\xi_{j t} .
$$

The coefficient in the above regression is the long run output elasticity of tax revenue, which measures the long run growth potential of revenue source-j [Sobel and Holcombe (1996), Williams et al. (1973)].

However, for the short run analysis we apply the theory of co-integration as developed by Granger (1981) and later expanded by Engle and Granger (1987) integrating the short run dynamics with long run equilibrium relationships. ${ }^{30}$ In the short run if the tax revenue and income variables are co-integrated then there exists an error correction form such that the realised rate of growth of the actual revenue stream would depend on the growth rate of GDP and on the last period dis-equilibrium error from the long run relationship:

$$
g\left(R_{j t}\right)=a_{1 j} g\left(Y_{t}\right)+\rho_{1} \xi_{t-1}+v_{j t} .
$$

In (3.3) $a_{1 j}$ measures the sensitivity of tax revenue with respect to output. Note that $\left(-1<\rho_{1}<0\right)$ shows the speed at which the error, $\xi_{j t-1}=\ln R_{j t-1}-\left\lfloor\gamma_{0 j}+\gamma_{1 j} \ln Y_{t-1}\right\rfloor$, corrects the growth of tax revenue. If the revenue obtained in the previous period exceeds the long run target

${ }^{28}$ Appendix 1 illustrates some sample properties of the various revenue categories and GDP profile over the period 1950-2000

${ }^{29}$ One has to be cautious with revenue flows since the realised values of tax revenue depend not only on risk factors such as the business cycle, but also on structural changes in the tax and spending codes and the rate schedule, albeit with a lag. A typical example would be an anticipatory counter-cyclical fiscal policy to combat a bad state of nature. However, as Barro (1979) has argued, governments appear not to change the rate schedule and tax code too frequently due to concern over the efficiency costs of the tax system. Thus even though observed variations in the growth rates of revenues may suffer from the noise due to legislative tinkering with the tax code, we show that one may still obtain an estimate of the risk premiums implicit in the tax revenue flows. See also Groves and Kahn (1952).

${ }^{30}$ If in fact GDP and the revenue variables are found not to be co-integrated, it implies that either there is no long run relationship between the two variables or that there is a third variable that is missing from the specification. 
then $\xi_{j t-1}>0$, and given $\rho_{1}<0$, it will reduce this period's revenue growth. The closer to zero is this parameter the slower will be the speed of adjustment. The precise short-run error correction model we estimate has a constant term as well: ${ }^{31}$

$$
g\left(R_{j t}\right)=a_{0 j}+a_{1 j} g\left(Y_{t}\right)+\rho_{1} \xi_{t-1}+v_{j t}
$$

Evidently in the absence of co-integration, we would estimate (3.4) without the dis-equilibrium error term. The co-integration results are briefly reviewed in appendix 2 , where we find evidence that the personal income tax (PIT) and total tax (TOT) revenue streams are co-integrated with GDP, while the remaining revenues are not co-integrated with GDP. The short run results are presented in Table 3.1, which demonstrate that there is a strong relationship between the growth behaviour of tax revenue streams and the evolution of the macro economy. The largest short run tax elasticity is obtained for the corporate tax revenue. A one percent drop in economic growth results in nearly four percent drop in the growth rate of CIT revenue. Even though there may appear no significant relationship between the two variables in the long run, there is indeed a strong relationship in short run fluctuations suggesting that CIT revenue carries systematic risk.

Each of personal, total tax revenue, and the social insurance contributions (SIC) has income elasticity at least as large as unity. However, for both PIT and TOT, the growth rate also depends strongly on last period's disequilibrium error. In fact, if the last period revenue increased beyond the sustainable long run rate, the growth of revenue will fall by half that amount the following year. This implies that the federal government cannot increase the tax rate and expect an increase in the future growth rate of tax revenue if such a hike is not warranted by economic fundamentals. The speed of adjustment to the long run equilibrium seems extremely rapid (i.e., two years for total revenue). Indeed it is intuitive that tax revenue cannot grow beyond that is dictated by long run conditions. The least responsive is the excise tax (EXT) revenue, admittedly a minor category.

Estimating (3.4), it can be seen that the long-run output elasticity for PIT and TOT are each close to unity, and given that these variables are also co-integrated with output, from equation (3.2) it would follow that $E\left\{g\left(R_{j t}\right)\right\}=E\{g(Y)\} .{ }^{32}$ In other words, the steady state revenue growth, for both total and personal income taxes, would equal the long run growth of the economy.

\begin{tabular}{|cccccc|}
\hline \multicolumn{6}{c}{ Table 3.1: Short run Income Sensitivity of Tax Revenue: 1950 - 2000 } \\
\hline Name & Constant & Short-Run & Error Correction & Adjusted & D.W. \\
& Term: $a_{0 j}$ & Elasticity $a_{1 j}$ & Term & R-Sq & \\
GTOT with GGDP & 0.0001 & $1.1747^{*}$ & $-0.5606^{*}$ & 0.562 & 1.75 \\
& $(0.0116)$ & $(0.2877)$ & $(0.1358)$ & & \\
GPIT with GGDP & -0.0051 & $1.4452^{*}$ & $-0.3355^{*}$ & 0.471 & 1.37 \\
& $(0.01421)$ & $(0.3524)$ & $(0.1137)$ & & \\
\hline
\end{tabular}

\footnotetext{
${ }^{31}$ Note that where the revenue variables are co-integrated with output, the intercept term in (3.4) would drop out, and hence not be statistically significant (which is indeed the case for TOT and PIT in Table 3.1).

${ }^{32}$ Indeed using the dynamic ordinary least squares method (DOLS) as was suggested by Hayashi (2000) we obtain elasticities of 1.06 and 1.04, respectively, for PIT and TOT (Ahsan-Tsigaris, 2002).
} 


\begin{tabular}{|lccccc|}
\hline GCIT with GGDP & $-0.1094^{*}$ & $3.7606^{*}$ & NA & 0.317 & 2.51 \\
& $(0.0319)$ & $(0.7648)$ & & & \\
GSIC with GGDP & $0.0296^{*}$ & $1.0299^{*}$ & NA & 0.172 & 1.91 \\
& $(0.0130)$ & $(0.3048)$ & & & \\
\multirow{2}{*}{ GEXT with GGDP } & 0.0017 & 0.1794 & NA & 0.000 & 1.97 \\
& $(0.0246)$ & $(0.5909)$ & & & \\
\hline
\end{tabular}

Notes: * indicates significant at the 1\% level. NA denotes the non-applicability of the error term, as the variables in question happen not to be co-integrated with output.

3.2 Relative Asset Returns and GDP Sensitivity: We now examine the risk embedded in the tax revenue flows vis-à-vis the market in terms of their relative GDP sensitivity. To do this we start with equation (2.12), and interpret the $j$-th asset as being the underlying non-traded asset that has claims on the relevant revenue flows, and whose combined earnings and dividend growth mimics the growth rate of the revenue source-j: $g\left(R_{j t}\right)=\left\{g\left(I_{j t}\right)+d_{j t}\right\}$. In the process, we modify (2.12) by adding an intercept term, and an error correction term for PIT and TOT. The latter feature requires one to enter the GDP variable in terms of deviations from its mean, and thus we obtain:

$$
g\left(R_{j t}\right)-\left(g\left(I_{m t}\right)+d_{m t}\right)=\left(a_{0 j}-a_{0 m}\right)+\left(a_{1 j}-a_{1 m}\right)\left(g\left(Y_{t}\right)-\bar{g}\right)+\rho_{1} \xi_{t-1}+w_{j t} .
$$

Table 3.2 presents the differences in the average growth rates and their significance. This is the intercept term of the above equation. While the focus of the discussion here is the revenue behaviour and the market rate of return, i.e., the last row, the table below includes the relative pattern of growth between tax categories as well. ${ }^{33}$ The interesting fact to note is that the difference between the growth rate of revenue flows and average growth rate of earnings per share (inclusive of the dividend yield) of the S\&P500 index is not statistically significant except for EXT and CIT, where both grew on average at a lower rate than the total return on the market portfolio. In other words, we find that PIT, SIC and TOT categories do on average grow at about the same rate as GDP.

In Table 3.3 we examine the relative short-run output elasticities of the total return between different assets. From (3.5) it is obvious that were the $i$-th asset be the market portfolio, the net elasticity is merely $\left(a_{l j}-a_{l m}\right)$. Recall that these $a_{l k}$-terms $(k=j, m)$ form the parameters of the implicit risk premium relevant for the non-traded asset as described in (2.16) above. Here again the focus of attention lies in the last row; however, for the sake of completeness all revenue sources are also included in the estimation. Comparing various revenue growth rates relative to the growth rate of total revenue, (i.e., the GTOT-row), we find that while all revenue sources carry some systematic risk, CIT and EXT (though a minor source) are more volatile than PIT or SIC. Examining the last row, it is clear that we cannot reject the hypothesis that corporate tax revenue is as sensitive to macroeconomic volatility as the total return on the market portfolio, namely the S\&P 500 index. Indeed all other revenues would appear to belong to a lower risk class than the market.

\footnotetext{
${ }^{33}$ Indeed the mutual difference in growth rates of different revenue variables are not statistically significant in most cases with the exception of social insurance contributions.
} 


\begin{tabular}{|lcccccc|}
\hline \multicolumn{7}{c|}{ Table 3.2: Differences in Average Growth Rates, $\left(\boldsymbol{a}_{\mathbf{0} j}-\boldsymbol{a}_{\mathbf{0} \boldsymbol{m}}\right): \mathbf{1 9 5 0 - 2 0 0 0}$} \\
\hline GPIT & GPIT & GCIT & GSIC & GEXT & GTOT & GMP \\
GCIT & $0.025(0.113)$ & 0 & & & & \\
GSIC & $-0.018(0.044)$ & $-0.044(0.013)$ & 0 & & & \\
GEXT & $0.037(0.014)$ & $0.014(0.530)$ & $0.058(0.000)$ & 0 & & \\
GTOT & $0.004(0.277)$ & $-0.021(0.085)$ & $0.022(0.002)$ & $-0.033(0.018)$ & 0 & \\
GMP & $-0.014(0.411)$ & $-0.041(0.066)$ & $0.004(0.816)$ & $-0.054(0.008)$ & $-0.018(0.245)$ & 0 \\
\hline
\end{tabular}

Note: The dependent variable is the column variable minus the row variable; a positive (negative) coefficient value implies that the average growth rate of the column variable exceeded (fell below) that in the corresponding row variable. P-values are shown in parenthesis. GMP denotes the growth rate of earnings per share plus the dividend yield for the $S \& P 500$ index, which were obtained from Shiller.

\begin{tabular}{|lcccccc|}
\hline \multicolumn{6}{c|}{ Table 3.3: Relative Short-Run Sensitivity Measures, $\left(\boldsymbol{a}_{1 j}-\boldsymbol{a}_{1 \boldsymbol{m}}\right): \mathbf{1 9 5 0 - 2 0 0 0}$} \\
\hline GPIT & GPIT & GCIT & GSIC & GEXT & GTOT & GMP \\
GCIT & $1.03(0.183)$ & 0 & & & & \\
GSIC & $0.40(0.361)$ & $2.73(0.001)$ & 0 & & & \\
GEXT & $1.10(0.129)$ & $3.58(0.000)$ & $0.85(0.191)$ & 0 & & \\
GTOT & $0.16(0.371)$ & $0.84(0.168)$ & $-0.35(0.294)$ & $-0.97(0.157)$ & 0 & \\
GMP & $-1.41(0.097)$ & $1.19(0.214)$ & $-1.54(0.035)$ & $-2.39(0.007)$ & $-1.91(0.018)$ & 0 \\
\hline
\end{tabular}

Note: Column variable net of row variable creates the dependent variable; the independent variable is the unexpected GDP deviations from its drift. Positive (negative) coefficient means more (less) risky column relative to the corresponding row variable. P-values appear in the brackets against each estimate.

The next table re-estimates the relative short run elasticity measures without the Korean War years of 1950-1952. As seen in appendix 1, these years had most of the extreme values, and the volatility of many of the revenue flows would be higher than without these war years. Parameters reported in Table 3.4 suggest that the GDP-sensitivity figures become uniformly much sharper in the absence of the war, though qualitatively remaining much the same. While, corporate tax revenue remains statistically riskier than any other revenue category vis-à-vis the market portfolio, the coefficient is estimated with more precision when the Korean War years are excluded from the sample. ${ }^{34}$ In what follows we would illustrate the risk premium calculations using both sets of estimate, i.e., with and without the war years.

\footnotetext{
${ }^{34}$ This also allows us to examine the sensitivity of our results.
} 


\begin{tabular}{|lcccccc|}
\multicolumn{6}{|c|}{ Table 3.4: Relative Short-Run Sensitivity Measures, $\left(\boldsymbol{a}_{1 j}-\boldsymbol{a}_{1 \boldsymbol{m}}\right): \mathbf{1 9 5 3 - 2 0 0 0}$} \\
\hline GPIT & GPIT & GCIT & GSIC & GEXT & GTOT & GMP \\
GCIT & $-1.55(0.059)$ & 0 & & & & \\
GSIC & $0.47(0.317)$ & $2.95(0.001)$ & 0 & & & \\
GEXT & $1.24(0.114)$ & $3.79(0.001)$ & $0.83(0.267)$ & 0 & & \\
GTOT & $0.24(0.215)$ & $1.12(0.069)$ & $-0.46(0.193)$ & $-1.20(0.108)$ & 0 & \\
GMP & $-2.13(0.010)$ & $0.28(0.772)$ & $-2.68(0.001)$ & $-3.51(0.000)$ & $-2.57(0.001)$ & 0 \\
\hline
\end{tabular}

Note: Column variable net of row variable creates the dependent variable; the independent variable is the unexpected GDP deviations from its drift. Positive (negative) coefficient means more (less) risky column relative to the corresponding row. P-values appear in the brackets against each estimate.

\section{Implicit Risk Premium and Discount Rates}

From the above analysis it seems that the public revenue flows are risky and carry systematic or economy wide risk. Can we measure a pseudo beta for these flows as if the underlying assets actually traded in the market? Indeed the procedure described in section 2 yields an expression for the market risk premium equation, (2.13), which is reproduced below:

$$
b_{j}=1+\frac{a_{1 j}-a_{1 m}}{\lambda_{m}}
$$

The beta of any security is therefore equal to the beta of the market portfolio (which is unity) plus a factor that depends on the relative sensitivities of the total return (on asset-j vis-à-vis the market portfolio) to output growth, namely $\left(a_{1 j}-a_{1 m}\right)$. The latter coefficient is actually weighted by the inverse of the sensitivity of the market excess return to output growth (i.e., the denominator, $\lambda_{m}$ in 4.1).

The last row in each of Tables 3.3 and 3.4 above presented estimates of the coefficient $\left(a_{1 j}-a_{1 m}\right)$. All that remains is to obtain an estimate of $\lambda_{m}$ in order to compute the risk premium as measured by the beta specified here. Recall the specification of the market excess return as given by (2.12) above. Modelling the output term as deviations from trend, we have:

$$
\left(r_{m t}-r_{f t}\right)=a_{0}+\lambda_{m}\left(g\left(Y_{t+1}\right)-E\{g(Y))+e_{j t}\right.
$$

Using Shiller's data for the period 1950-1999 yields the following results:

$$
\begin{aligned}
& \hat{r}_{m t}-\hat{r}_{f t}=0.06348+3.1597\left(g\left(Y_{t+1}\right)-\bar{g}(Y)\right) \\
& t \text {-stats } \quad 4.15 \quad 4.74
\end{aligned}
$$

Adj. R - Sq .304, D.W. 1.55 
The sensitivity of the current excess return to the future growth of the economy is therefore estimated as 3.16. In other words, a one-percent drop in the future growth rate of output will reduce the expected current excess return in the market by about 3.16 percent. $^{35}$

The intercept term indicates the sample average excess return over the estimated period, i.e., the market risk premium is estimated at 6.35 percent. ${ }^{36}$ Over the entire sample period (1950-2000), the mean real return on the S\&P500 index has been 8.96 percent annually (inclusive of dividends). Thus, the average real risk free rate is obtained as the mean real return on the market net of market risk premium, 8.96-6.35 = 2.61. The latter equals the average real yield (over this period) on prime commercial paper of a 6-month maturity. ${ }^{37}$

Which risk free rate should the public sector use in figuring out the public discount rate? Textbooks usually introduce the notion of the risk free rate via portfolio choice theory, which postulates the existence of one risk-free asset, usually taken to be Treasury bills or comparable short-term sovereign debt. ${ }^{38}$ The annualized short-term rates presumably may not be suggestive of individual's forecast of the macroeconomic fundamentals (e.g., inflation). However, since we are interested in estimating the expected social discount rate over a 50-year period, the average value, over 50 years, of the annualized short term rates should be reflective of the macroeconomic fundamental in the long run. ${ }^{39}$ In the remainder of the paper we shall interpret the 2.61 figure as the real risk free rate of interest from the private market's point of view. ${ }^{40}$

Combining the estimated value of $\lambda_{\mathrm{m}}$ (from equation 4.2 above) with GDP sensitivity terms as reported in the last row of Table 3.3 above, we derive the beta (using equation 4.1) for all the assets that have exclusive claims on different tax categories analysed here. These are shown in the third column of Table 4.1 below. Following the security market equilibrium condition, the risk premia for different assets are calculated as the product of the market risk premium and the assetspecific beta's:

$$
\delta_{j}=r_{f t}+b_{j}\left[E\left(r_{m t}-r_{f t}\right)\right]
$$

Hence we calculate the risk premium associated with these specific revenue backed securities by merely multiplying the estimated beta's (column 3) with the excess return (estimated as 6.35 in equation 4.2). The outcome is shown in column four of Table 4.1.

The final column in Table 4.1, illustrates the discount rate applicable to projects, which would yield the revenue streams of riskiness as depicted by the left hand column in the table (see

\footnotetext{
${ }^{35}$ The sensitivity factor without the Korean War years happens to be similar at 3.2638.

${ }^{36}$ These figures are in accordance with the equity premium literature [e.g., Mehra and Prescott (1985)].

${ }^{37}$ See Robert J. Shiller, Market Volatility, MIT Press, Cambridge MA, 1989. Data have been updated online at http://www.econ.yale.edu/ shiller/data/chapt26.html

${ }^{38}$ Note that the qualification that the asset in question be sovereign debt is presumably meant to rule out any default risk. One may thus extend the argument to be just as applicable to AAA corporate bonds.

${ }^{39}$ Short run fluctuations in the risk free rate around its equilibrium value will tend to cancel out over a long period of years.

${ }^{40}$ If one were to argue that a longer horizon is relevant when it comes to evaluating both the yield and financing issues in public investments in infrastructure and the like, the "long" 10-year maturity yield on t-bills has a nominal average rate of 7.53 per annum (over the period 1962-99), while the average inflation rate was 4.06. Thus the real risk free rate over this period is around 3.47, which is higher than the 2.61 figure used above. Interestingly the one-year t-bill rate over the same horizon is 2.74 , which is rather close to the private sector's yield on 6-month certificates of deposit (2.612).
} 
equation 4.3). These rates merely add up the figures in column four and the relevant risk free rate (argued to be 2.61 percent from the private market's point of view). From the table we see that the financial markets would demand that any project that yields a pattern of return that mimics the corporate tax revenue stream face a very large risk premium. Indeed here the figure in question is even higher than that applicable on the market portfolio. However, the risk premium drops significantly if we use the other revenue categories as reflecting the return implicit in the corresponding assets.

The approach of this paper, namely the interpretation of tax revenues as the return on public investment, points out that while the investment is risky, the aggregate risk implicit in total revenue is far less volatile than the market portfolio. This then is the rationale for advocating a risk discount rate that is below the market rate. Indeed the figures highlighted above suggests that the discount rate applicable to total public revenue, which is typically the de facto collateral for all public debt, is merely 5.13 percent annually vis-à-vis the market rate of about nine percent (8.96, to be precise). This corresponds to a rebate of 43 percent on the market rate.

\begin{tabular}{|l|cccc|}
\hline \multicolumn{5}{|c|}{ TABLE 4.1: Risk Premiums and Discount Rates: $\mathbf{1 9 5 0}-\mathbf{2 0 0 0}$} \\
$\begin{array}{c}\text { Relative } \\
\text { Sensitivities } \\
\left(a_{1 j}-a_{1 m}\right)\end{array}$ & $\begin{array}{c}\text { Estimated } \\
\text { Beta }\left(b_{j}\right)\end{array}$ & $\begin{array}{c}\text { Market Risk } \\
\text { Premium }\end{array}$ & $\begin{array}{c}\text { Market } \\
\text { Borrowing Rate } \\
\left(\delta_{j}\right)\end{array}$ \\
\hline GCIT & 1.194 & 1.378 & 8.750 & 11.360 \\
GPIT & -1.405 & 0.555 & 3.526 & 6.136 \\
GSIC & -1.537 & 0.514 & 3.261 & 5.871 \\
GEXT & -2.388 & 0.244 & 1.551 & 4.161 \\
GTOT & -1.906 & 0.397 & 2.520 & 5.130 \\
GMP & 0.000 & 1.000 & 6.350 & 8.960 \\
\hline
\end{tabular}

Note: (a) The figures in this column are taken from the last row in Table 3.3.All computed values are in real terms.

How then one may rationalize the fact that the public sector is actually able to borrow at even lower rates, i.e., in a range of figures varying from 2.61 (six months) to the long-term (ten year) real rate of 3.47 percent as cited above, each of which corresponds to a zero value of beta? To us the reason this happens is due to the state's ability to engage in intergenerational risk sharing. Capital asset pricing models does not price securities that can spread aggregate risks across generations, only within the current generation. The intergenerational argument formalized by Gordon and Varian (1988), and further extended by Ahsan and Tsigaris (1998), states that the government's ability to pre-commit many unborn generations in sharing risks with the current generation implies that the risk premium applicable to the public sector becomes negligible. In other words, the systematic risk facing a given generation becomes in effect idiosyncratic when pooled with the independent lotteries of many generations to come. Consequently, the risk free rate emerges as the socially optimal discount rate. The above conclusion is similar to the much earlier result of Arrow-Lind (1970), though the rationale is different. In the latter context, the state was modelled as undertaking many uncorrelated risky projects at a point in time, which according to our empirical investigation does not appear to hold true. To the extent the results presented above are taken to be robust, it calls for a different explanation behind the validity of the risk free public discount rate. The rationale whereby the state 
pools uncorrelated risky revenues of many generations together would appear to be the dominant criterion.

We may thus interpret the difference between the risk-free borrowing rate and the above riskadjusted estimate as a measure of the dividend to society from the ability of the state to spread risk across generations. Using the Table 4.1 figures, the annual value of the generational risk-spreading dividend to society is merely the risk premium times net national debt, namely $2.52 \%$ of 6.095 trillion USD, i.e., 153.6 billion. ${ }^{41}$ On a per capita basis, the dividend comes to about $\$ 500$ annually in interest savings.

Peace Dividend: We next re-compute the risk premia and discount rates when the Korean War is excluded from the data set. Not surprisingly, we find that risk premia decline for all revenue categories. The short risk free rate happens to be 2.81, a little higher than before, while the risk premium drops to 5.48. Consequently, the public risk discount rate (using TOT) reduces to 3.97 percent, as in Table 4.2), which represents an even larger rebate of 52 percent on the market rate, which in turn also falls a little ( 8.29 vs. 8.96 before). We interpret the difference the borrowing costs implied by our analysis for the two data sets as the "peace dividend", i.e. the difference between figures in the last column of Table 4.1 less those in column 5 in Table 4.2. The peace dividend in terms of lower borrowing costs for the public sector from not having war exceeds one percent (i.e., 5.13 minus 3.97, or, 1.16, more precisely) for the total tax revenue stream. At the current debt level, the above dividend figure would correspond to an annual saving to the tune of 70.5 billion dollars. ${ }^{42}$

\begin{tabular}{|l|ccccc|}
\multicolumn{5}{|c|}{ TABLE 4.2: Risk Premiums and Discount Rates: 1953-2000 } \\
\hline & $\begin{array}{c}\text { Relative } \\
\text { Sensitivities } \\
\left(a_{1 j}-a_{1 m}\right)\end{array}$ & $\begin{array}{c}\text { Estimated } \\
\text { Beta }\left(b_{j}\right)\end{array}$ & Market Risk & $\begin{array}{c}\text { Borrowing Rate } \\
\left(\delta_{j}\right)\end{array}$ & $\begin{array}{c}\text { Peace } \\
\text { Dividend }\end{array}$ \\
\hline GCIT & 0.276 & 1.0846 & 5.9430 & 8.754 & 2.605 \\
GPIT & -2.129 & 0.3477 & 1.9905 & 4.717 & 1.420 \\
GSIC & -2.677 & 0.1798 & 0.9850 & 3.797 & 2.074 \\
GEXT & -3.511 & -0.0757 & -0.4150 & 2.397 & 1.764 \\
GTOT & -2.572 & 0.2120 & 1.1610 & 3.973 & 1.157 \\
GMP & 0.000 & 1.000 & 5.4795 & 8.291 & 0 \\
\hline
\end{tabular}

Note: (a) The figures in this column are taken from the last row in Table 3.4. All computed values are in real terms

\section{Conclusion, Extension and Further Work}

Until now the literature on the proper risk discount rate for public investment has been of an analytical nature, the primary contributors being Arrow-Lind, Hirshleifer and Sandmo. In all these contexts the rate of discount applicable to a public investment is argued to depend, at least in principle, on the type of investment. The different conclusions arising from these studies amount to

\footnotetext{
41 The debt figures used in this illustration is taken form the US Debt Clock, US Treasury which on June on June 14, 2002 stood at 6.095 trillion dollars. This figure translates to an outstanding debt of $\$ 21,199$ per person.

42 The latter figure is calculated at 0.0116 times the national debt.
} 
questioning whether the returns from public investment correlate well with the GDP components, and this must ultimately be an empirical matter. Indeed the above authors themselves had argued in a similar vein. In this paper, we devise a mechanism that enables us to actually carry out the test. We have argued that it is conceptually correct to treat a portion of the tax revenue collected by the government as due return on public investment in infrastructure that accrues to the public sector. The co-variability between the return from public investment and GDP then simplifies to one between government revenue flows and GDP.

We find that revenue component such as the CIT is highly correlated with the market. For investment in public goods, however, it is the aggregate revenue that ought to matter. And at that level the relevant risk premium is fairly small in absolute terms. The gap between the (real) risk free rate and the risk adjusted social discount rate for total revenue is about two percentage points. Another way of looking at that statistic is to reflect that the risk adjusted public discount rates cited above are a mere fraction (half or even less) of the rate applicable to private projects of average (i.e., equal to market) risk. Major wars are likely to add to macro risks, and we detect some evidence of this happening based on the Korean War period.

In conclusion, we believe that the empirical determination of the risk discount rate applicable for pubic investment is an important but hitherto neglected topic. Other possible applications of the methodology described in the paper can be used to estimate risk premiums of different types of human capital investments, small business valuations, social insurance benefits, and other publicly non-traded assets. Finally, nesting the intergenerational risk shifting aspects of the debate into the design of econometric specification could be explored in future work. 


\section{References}

Ahsan, S. M. and P. Tsigaris, (2002), "Long-run Behaviour of Tax Revenues and Sustainable Debt Management", (in progress).

Ahsan, S. M. and P. Tsigaris, (1998), "The Design of a Consumption Tax under Capital Risk", Journal of Economics /Zeitschrift fuer Nationaloekonomie, 68(1), 53-78.

Arrow, K.J., and R.C. Lind, (1970), "Uncertainty and the Evaluation of Public Investment Decisions," American Economic Review, 60, 364-378.

Bulow J.I. and L.H. Summers, (1984), "Taxation of Risky Assets," Journal of Political Economy, 92, 20-39.

Burmeister E., and K.D. Wall, (1986), “The Arbitrage Pricing Theory and Macroeconomic Factor Measures, The Financial Review, 21 (1), p 1-20.

Chen, N., R. Roll, and S.A. Ross, (1986), "Economic Forces and the Stock Market: Testing the APT and Alternative Asset Pricing Theories." Journal of Business, 59 (3), 383-403.

Dickey, D. A., and W. A. Fuller, (1979), "Distribution of the Estimators for Autoregressive Time Series with a Unit Root," Journal of the American Statistical Association, 74, 366, 427-431.

Eaton, J. and H.S. Rosen, (1980a), "Labour Supply, Uncertainty, and Efficient Taxation," Journal of Public Economics, 14, 365-374.

Eaton, J. and H. Rosen, (1980b), "Taxation, Human Capital, and Uncertainty," American Economic Review, 70 (4), 705-715.

Engel, R. F., and C.W.J. Granger, (1987), "Co-integration and Error Correction: Representation, Estimation, and Testing," Econometrica, 55, 2, 251-276.

Gordon, R.H., (1985), "Taxation of Corporate Capital Income: Tax Revenues Versus Tax Distortions," Quarterly Review of Economics, 100(1), 1-27.

Gordon, R.H., and H.R. Varian, (1988), "Intergenerational Risk Sharing," Journal of Public Economics, 37, 185-202.

Groves, H. M., and C.H. Kahn, (1952), “The Stability of State and Local Tax Yields," American Economic Review, 42, 2, 111-20.

Granger, C. (1981), "Some Properties of Time Series Data and their Use in Econometric Model Specification." Journal of Econometrics, 16, pp. 121-130.

Hamilton, J.H., (1987), "Taxation, Savings, and Portfolio Choice in a Continuous Time Model," Public Finance, 42 (2), 264-282.

Hayashi F., 2000, Econometrics, Princeton University Press.

Hirshleifer, J., (1964) "Efficient Allocation of Capital in an Uncertain World," American Economic Review, 77-85.

Hirshleifer, J., (1966) "Investment Decision under Uncertainty: Applications of the State-Preference Approach," Quarterly Journal of Economics, 80, 252-77.

Lintner, J. (1965), "The Valuation of Risk Assets and the Selection of Risky Investments in Stock Portfolios and Capital Budgets," Review of Economics and Statistics, 13-37.

Maddison A. (1991), The Dynamic Forces in Capitalist Development: A Long Run Comparative View. Oxford, Oxford University Press. 
Mehra, R. and E.C. Prescott, (1985), “The Equity Premium: A Puzzle”, Journal of Monetary Theory, 15, 145-61.

Mossin, J., (1966), "Equilibrium in a Capital Asset Market," Econometrica, 768-83.

Pauly, M. (1970), "Risk and the Social Rate of Discount", American Economic Review, 60(1), 195-98.

Ross, S.A. (1976), "The Arbitrage Pricing Theory of Capital Asset Pricing." Journal of Economic Theory, 4, $341-360$

Samuelson, P.A. (1964), "Principles of Efficiency: Discussion," American Economic Review, P\&P, 54, 93-96.

Sandmo, A., (1972), "Discount Rates for Public Investment Under Uncertainty," International Economic Review, 13, 287-302.

Sharpe, W. F., (1964), "Capital Asset Prices: A Theory of Market Equilibrium under Conditions of Risk”, J of Finance, 19, 425-42.

Shiller, R., (1981), "Do Stock Prices Move Too Much to be Justified by Subsequent Changes in Dividends," American Economic Review, 421-36.

Shiller, R., (1993), "Macro Markets: Creating Institutions for Managing Society's Largest Economic Risks," Clarendon Lectures in Economics, Oxford University Press.

Sobel, R. S., and R. G. Holcombe (1996), "Measuring the Growth and Variability of tax Bases over the Business Cycle," National Tax Journal, 49 (4), 535-52.

Varian H.R. (1980), "Redistributive taxation as social insurance." Journal of Public Economics, 31, 23751.

Vickrey, W., (1964), "Principles of Efficiency: Discussion," American Economic Review, P\&P, 54, 88-92.

Williams, W.V., R.M. Anderson, D.O. Froehie, and K.L. Lamb, (1973), "The Stability, Growth and Stabilizing Influence of State Taxes," National Tax Journal, 26, 2, 267-74. 


\section{Appendix 1: The Pattern of the Revenue and Expenditure Flows}

Our data covers the period 1950-2000 and are obtained from the Office of Management of Budget (OMB) website. ${ }^{43}$ Figure A1 below shows the pattern of personal, corporate, social insurance contributions, excise and total tax revenue, in real terms, over the above period. ${ }^{44}$ From the pattern of the data we can see that the personal, social insurance contributions and total tax revenue have trended

upwards with fluctuations along the path, while corporate and the excise tax revenue do not show any apparent trend other than being very volatile. This is a first indication that the variables may be non-stationary, which if verified, would have important implication in the estimation

Figure A1: Various Tax Revenue Flows: 1950-2000

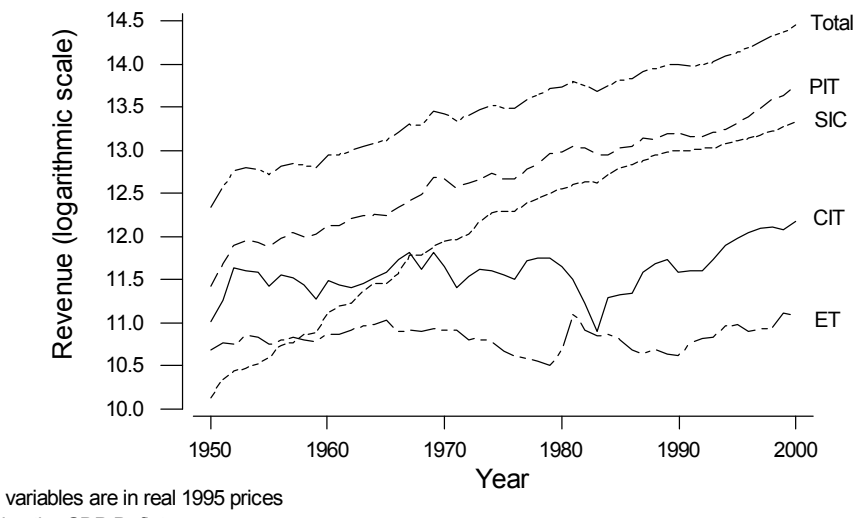

using the GDP Deflator work to be described below.

Table A.1 provides us with some descriptive statistics on the real growth in various tax revenue, $g\left(R_{j t}\right)$, and payments to persons for the US (federal) government over the same period. These include sample results such as the sample mean or drift parameter, standard deviation of the growth rate, significance of the sample average, the range of values and the growth rate computed from a deterministic trend line with its corresponding significance. ${ }^{45}$ Just as figure 1 indicated average rates of growth have been positive and quite large for the three largest tax revenue sources. The largest average growth is observed in social insurance contributions (SIC). The highest standard deviation is observed, not unexpectedly, in the case of the corporate income $\operatorname{tax}$ (CIT). We note that the volatility of CIT growth is significantly higher than most other public flows; the standard deviation for CIT is approximately 15 percent vs. 7 percent for the growth rate of the personal income tax revenue. The t-stats column for the sample average growth rate

\footnotetext{
${ }^{43}$ The website is http://www.access.gpo.gov/usbudget/index.html. Table 2.1 of the historical data were used for the main tax receipts categories such as individual income tax receipts, corporate income tax receipt, social insurance contributions and retirement receipts, excise tax, and total receipts. The GDP and the deflator were obtained from table 10.1 of the same source. The payments to individuals, direct payments as well as grants to state and local authorities, were obtained from table 11.1.

${ }^{44}$ The OMB data is on a fiscal year basis, which in the US case, begins in October 30 and ends on the subsequent September 30. Prior to 1977, the fiscal year started on July 1 and ended on June 30 of the subsequent year. GDP and deflators have been adjusted to reflect the fiscal year basis, and were obtained from the same source. There are data on various receipts available from National Income and Public Accounts (NIPA) of the Bureau of Economic Analysis of the U.S. Department of Commerce. The website is at http://www.bea.doc.gov. This site also contains historical data on federal, state and local receipts, however on a calendar year basis.

${ }^{45}$ The sample mean is computed as the average of the sample of the difference in the series and hence would represent the drift parameter in a random walk process of the type $\Delta \ln R_{i t}=a_{i}+u_{i t}$. Alternatively, we also present the average growth rate using the trend regression line given as follows: $\ln R_{i t}=a_{i}+g_{i} t+u_{i t}$ as was computed by Williams et al. When there is no confusion, we would denote the growth rate of revenue-i as $\mathrm{g}_{\mathrm{i}}$.
} 
indicates that all the average growth rates are significant except for the corporate tax and the excise tax revenue. ${ }^{46}$ One can observe that the year-on-year fluctuations in corporate tax revenue have been most volatile during the 1950-2000 period rendering its sample average value insignificant. Volatility in many of the flows is also apparent from the observed large revenue growth and reduction in payments to individuals due to the expansion of economic activity (1951-52) and financing defence spending for the Korean War. Moreover, the recession of the early 80s caused corporate tax revenue to drop by 33 percent in $1983 .{ }^{47}$ The table also shows that growth rate of GDP, denoted by $Y$, over the same period has been very stable, which would imply a degree of flexibility of the tax system in absorbing aggregate risks. ${ }^{48}$

\begin{tabular}{|c|c|c|c|c|c|c|c|}
\hline Variable & $\begin{array}{l}\text { Average } \\
\text { Mean G }\end{array}$ & $\begin{array}{l}\text { Stdev of } \\
\text { owth rate }\end{array}$ & t-stats & $\begin{array}{l}\text { Minimum } \\
\text { Growth Rate }\end{array}$ & $\begin{array}{r}\text { Maximum } \\
\text { Growth Rate } \\
\text { (year) }\end{array}$ & $\begin{array}{r}\text { Trend line } \\
\text { growth } \\
\text { Rate }^{49}\end{array}$ & $\begin{array}{r}\text { t-stats for } \\
\text { trend } \\
\text { growth rate }\end{array}$ \\
\hline GPIT & 0.0462 & 0.069 & 4.751 & $-0.096(71)$ & $0.264(51)$ & 0.0371 & 40.63 \\
\hline GCIT & 0.0217 & 0.151 & 1.030 & $-0.328(83)$ & $0.393(84)$ & 0.0093 & 4.34 \\
\hline GSIC & 0.0655 & 0.055 & 8.587 & $-0.007(76)$ & $0.217(51)$ & 0.0625 & 36.42 \\
\hline GEXT & 0.0080 & 0.095 & 0.602 & $-0.185(82)$ & $0.425(81)$ & 0.0008 & 0.54 \\
\hline GTOT & 0.0416 & 0.061 & 4.863 & $-0.079(71)$ & $0.217(51)$ & 0.0354 & 50.26 \\
\hline $\mathrm{G}(\mathrm{Y})$ & 0.0349 & 0.023 & 10.830 & $-0.020(75)$ & $0.108(51)$ & 0.0333 & 89.15 \\
\hline
\end{tabular}

Notes. GPIT: Annual growth rate of the personal income tax revenue; GCIT: Annual growth of corporate income tax revenue; GSIC: Annual rate of growth of social insurance tax and contributions; GEXT; growth rate of excise tax revenue; GTOT: growth of total tax revenue; $G(Y)$ is the growth rate of GDP. The growth rates are computed as the difference in the natural logarithm from year to year. All data have been adjusted for inflation using the GDP deflator.

\section{Appendix 2: Co-Integration of Revenue Flows with GDP}

In order to examine if the revenue variables are co-integrated with GDP we estimate (3.2) and apply three tests to examine if the two variables are co-integrated. The test are the co-integrating regression Durbin Watson test, the augmented (where relevant) Dickey-Fuller test, the unrestricted VAR. ${ }^{50}$ We find that the personal income tax and the total revenue are co-integrated with GDP. Evidence

\footnotetext{
${ }^{46}$ Although the estimated growth from the trend line is significant for CIT but of a lower value. Notice also the reduction in the average growth rates for GRPIT, and GRT that brings more into line with the average growth rate of the economy.

${ }^{47}$ The drop occurred in 1983 due to the fiscal year reporting issue otherwise as shown in the corporate profits tax liability column this occurred in 1982 which was a recession year.

${ }^{48}$ The above average GDP growth figure is consistent with the findings of Maddison (1991), which clearly reflects the secular growth in total factor productivity.

${ }^{49}$ These were estimated by first by Williams et al. for the state governments and were expected that these would be highly positively correlated with the long run income elasticity of the tax.

${ }^{50}$ The tests used were suggested by Engel and Granger (1987). The CRDW and the augmented Dickey-Fuller are considered more powerful tests.
} 
indicates that CIT, SIC, and ET are not co-integrated with GDP. ${ }^{51}$ The table below presents the results:

\begin{tabular}{|c|c|c|c|c|c|}
\hline $\begin{array}{l}\text { Co-Integrating } \\
\text { Economic } \\
\text { Variables }\end{array}$ & $\begin{array}{r}\text { Estimated } \\
\text { Co- } \\
\text { Integrating } \\
\text { Coefficient } \\
\text { using OLS }\end{array}$ & $\begin{array}{r}\text { Adjusted } \\
\text { R-Sq } \\
\text { From } \\
\text { OLS } \\
\text { Estimation }\end{array}$ & $\begin{array}{r}\text { The } \\
\text { CRDW } \\
\text { Test: } \\
\text { DW }=0\end{array}$ & $\begin{array}{r}\text { Augmented } \\
\text { DF } \\
\text { Test } \\
\gamma=0^{52}\end{array}$ & $\begin{array}{r}\text { Unrestricted } \\
\text { VAR } \\
\text { Test: } \\
2 *\left(\mathrm{~F}_{1}+\mathrm{F}_{2}\right)\end{array}$ \\
\hline PIT with GDP & $\begin{array}{r}1.1168 \\
(0.02125)\end{array}$ & 0.982 & 0.60 & -4.02 & 37.76 \\
\hline CIT with GDP & $\begin{array}{r}0.2845 \\
(0.06303)\end{array}$ & 0.279 & 0.45 & -2.53 & 22.50 \\
\hline SIC with GDP & $\begin{array}{r}1.8871 \\
(0.03827)\end{array}$ & 0.980 & 0.14 & -0.73 & 24.42 \\
\hline ET with GDP & $\begin{array}{r}0.0201 \\
(0.03983)\end{array}$ & 0.000 & 0.48 & -2.40 & 6.46 \\
\hline TOT with GDP & $\begin{array}{r}1.0658 \\
(0.0144)\end{array}$ & 0.991 & 0.96 & -4.95 & 48.84 \\
\hline
\end{tabular}

Note: The standard errors are reported below the estimated coefficients. The CRDW co-integration test is based on the Durbin Watson Statistics with an Ho: D.W. $=0$. The critical value as reported by Sargan and Bhargava based on 10,000 simulations formed from 100 observations at the 5\% level of significance is D.W. 0.386. Care must be exercised since we have only 50 observations. We use $1 \%$ level of significance instead of $5 \%$ to account for the lower number of observations. The CRDW critical value of is 0.511 . On the basis of this test only PIT and TOT seem to be co-integrated. The critical value for the co-integration test at the 5\% is the Dickey-Fuller t-statistics equal to -3.41 based on 50 observations. This is obtained from Fuller (1996, Table 10.A.2). Thus we reject Ho of no co-integration if the t-statistics is greater than 3.41 in absolute terms. From the table all the variables are not co-integrated except total, personal income tax revenue with GDP. This augmented Dickey-Fuller test reconfirms the CRDW test. The critical value for the unrestricted VAR at the 1\% level of significance is 23.4 .

\footnotetext{
${ }^{51}$ The absence of co-integration does not imply that a short run relationship does not exists between the two variables since differencing makes them stationary and the results cannot be spurious.

${ }^{52}$ The Augmented Dickey-Fuller test did not include a constant term or a time trend in the auxiliary regression. The number of lags included in the augmented Dickey-Fuller test are 0 for CIT, 1 for PIT, 0 for SIC, 0 for ET, 1 for SIB, 1 for TOT, 0 for CRP.
} 


\section{CESifo Working Paper Series}

(for full list see www.cesifo.de)

756 Jan K. Brueckner, Internalization of Airport Congestion: A Network Analysis, July 2002

757 Lawrence M. Kahn, The Impact of Wage-Setting Institutions on the Incidence of Public Employment in the OECD: 1960-98, July 2002

758 Sijbren Cnossen, Tax Policy in the European Union, August 2002

759 Chandima Mendis, External Shocks and Banking Crises in Developing Countries: Does the Exchange Rate Regime Matter?, August 2002

760 Bruno S. Frey and Lars P. Feld, Deterrence and Morale in Taxation: An Empirical Analysis, August 2002

761 Lars Calmfors and Åsa Johansson, Nominal Wage Flexibility, Wage Indexation and Monetary Union, August 2002

762 Alexander R. W. Robson and Stergios Skaperdas, Costly Enforcement of Property Rights and the Coase Theorem, August 2002

763 Horst Raff, Preferential Trade Agreements and Tax Competition for Foreign Direct Investment, August 2002

764 Alex Cukierman and V. Anton Muscatelli, Do Central Banks have Precautionary Demands for Expansions and for Price Stability? - Theory and Evidence, August 2002

765 Giovanni Peri, Knowledge Flows and Knowledge Externalities, August 2002

766 Daniel Friedman and Nirvikar Singh, Equilibrium Vengeance, August 2002

767 Sam Bucovetsky and Michael Smart, The Efficiency Consequences of Local Revenue Equalization: Tax Competition and Tax Distortions, August 2002

768 Tapio Palokangas, International Labour Market Regulation and Economic Growth with Creative Destruction, August 2002

769 Rudi Dornbusch, The New International Architecture, September 2002

770 Hans-Werner Sinn, Weber's Law and the Biological Evolution of Risk Preferences: The Selective Dominance of the Logarithmic Utility Function, September 2002

771 Thomas Mayer, The Macroeconomic Loss Function: A Critical Note, September 2002

772 Seppo Honkapohja and Kaushik Mitra, Learning Stability in Economies with Heterogenous Agents, September 2002 
773 David Laidler, Inflation Targets Versus International Monetary Integration - A Canadian Perspective, September 2002

774 Morten I. Lau, Panu Poutvaara, and Andreas Wagener, The Dynamic Cost of the Draft, September 2002

775 Steven Brakman, Harry Garretsen, and Charles van Marrewijk, Locational Competition and Agglomeration: The Role of Government Spending, September 2002

776 Anke S. Kessler and Christoph Lülfesmann, The Theory of Human Capital Revisited: On the Interaction of General and Specific Investments, September 2002

777 Kjell Erik Lommerud, Frode Meland and Lars Sørgard, Unionized Oligopoly, Trade Liberalization and Location Choice, September 2002

778 Antonio Merlo and François Ortalo-Magné, Bargaining over Residential Real Estate: Evidence from England, September 2002

779 Yu-Fu Chen and Michael Funke, Exchange Rate Uncertainty and Labour Market Adjustment under Fixed and Flexible Exchange Rates, September 2002

780 Michael S. Michael, International Migration, Income Taxes and Transfers: A Welfare Analysis, September 2002

781 Clemens Fuest and Alfons Weichenrieder, Tax Competition and Profit Shifting: On the Relationship between Personal and Corporate Tax Rates, October 2002

782 Jan Bouckaert and Hans Degryse, Softening Competition by Enhancing Entry: An Example from the Banking Industry, October 2002

783 Johann K. Brunner and Susanne Pech, Adverse Selection in the Annuity Market with Sequential and Simultaneous Insurance Demand, October 2002

784 Gregory D. Hess and Eduard Pelz, The Economic Welfare Cost of Conflict: An Empirical Assessment, October 2002

785 Jan Erik Askildsen, Uwe Jirjahn, and Stephen C. Smith, Works Councils and Environmental Investment: Theory and Evidence from German Panel Data, October 2002

786 Geir H. Bjønnes, Dagfinn Rime, and Haakon O. Aa. Solheim, Volume and Volatility in the FX-Market: Does it matter who you are?, October 2002

787 John Evans and John Fingleton, Entry Regulation and the Influence of an Incumbent Special Interest Group, October 2002

788 Wolfgang Ochel, International Comparisons and Transfer of Labour Market Institutions, October 2002

789 B. Gabriela Mundaca, Moral Hazard Effects of Bailing out under Asymmetric Information, October 2002 
790 Gene M. Grossman and Edwin L.-C. Lai, International Protection of Intellectual Property, October 2002

791 John Hassler, José V. Rodriguez Mora, Kjetil Storesletten, and Fabrizio Zilibotti, A Positive Theory of Geographic Mobility and Social Insurance, October 2002

792 Paul De Grauwe and Marianna Grimaldi, The Exchange Rate in a Model with Heterogeneous Agents and Transactions Costs, October 2002

793 Guido Friebel and Mariassunta Giannetti, Fighting for Talent: Risk-shifting, Corporate Volatility, and Organizational Change, October 2002

794 Jan Erik Askildsen, Badi H. Baltagi, and Tor Helge Holmås, Will Increased Wages Reduce Shortage of Nurses? A Panel Data Analysis of Nurses' Labour Supply, October 2002

795 Marko Köthenbürger and Panu Poutvaara, Social Security Reform and Intergenerational Trade: Is there Scope for a Pareto-Improvement?, October 2002

796 Paul De Grauwe and Laura Rinaldi, A Model of the Card Payment System and the Interchange Fee, October 2002

797 Volker Böhm and Tomoo Kikuchi, Dynamics of Endogenous Business Cycles and Exchange Rate Volatility, October 2002

798 Mariam Camarero, Javier Ordóñez, and Cecilio Tamarit, The Euro-Dollar Exchange Rate: Is it Fundamental?, October 2002

799 Misa Tanaka, How Do Bank Capital and Capital Adequacy Regulation Affect the Monetary Transmission Mechanism?, October 2002

800 Jörg Baten and Andrea Wagner, Autarchy, Market Disintegration, and Health: The Mortality and Nutritional Crisis in Nazi Germany, 1933-1937, October 2002

801 Saku Aura, Uncommitted Couples: Some Efficiency and Policy Implications of Marital Bargaining, October 2002

802 Wolfram F. Richter, Delaying Integration of Immigrant Labor for the Purpose of Taxation, October 2002

803 Gil S. Epstein and Shmuel Nitzan, The Politics of Randomness, October 2002

804 John Hassler and José V. Rodriguez Mora, Should UI Benefits Really Fall over Time?, October 2002

805 Friedrich Breyer and Stefan Felder, The Dead-anyway Effect Revis(it)ed, October 2002

806 Assar Lindbeck and Solveig Wikström, E-exchange and the Boundary between Households and Organizations, November 2002 
807 Dieter Bös, Contests Among Bureaucrats, November 2002

808 Steven Brakman, Harry Garretsen, and Marc Schramm, The Strategic Bombing of German Cities during World War II and its Impact on City Growth, November 2002

809 Florian Englmaier and Achim Wambach, Contracts and Inequity Aversion, November 2002

810 Sarbajit Sengupta, Delegating Recruitment under Asymmetric Information, December 2002

811 Rajshri Jayaraman, On the Partial Public Provision of a Private Good, December 2002

812 Stéphanie Stolz, Banking Supervision in Integrated Financial Markets: Implications for the EU, December 2002

813 Christian Keuschnigg, Taxation of a Venture Capitalist with a Portfolio of Firms, December 2002

814 Inés Macho-Stadler and David Pérez-Castrillo, Settlement in Tax Evasion Prosecution, December 2002

815 Rainer Niemann and Dirk Simons, Costs, Benefits, and Tax-induced Distortions of Stock Option Plans, December 2002

816 Jan-Egbert Sturm and Barry Williams, Deregulation, Entry of Foreign Banks and Bank Efficiency in Australia, December 2002

817 V. Anton Muscatelli, Patrizio Tirelli, and Carmine Trecroci, Monetary and Fiscal Policy Interactions over the Cycle: Some Empirical Evidence, December 2002

818 Claude Hillinger, A General Theory of Price and Quantity Aggregation and Welfare Measurement, December 2002

819 Erkki Koskela and Ronnie Schöb, Optimal Capital Taxation in Economies with Unionised and Competitive Labour Markets, December 2002

820 Sheilagh Ogilvie, Guilds, Efficiency, and Social Capital: Evidence from German ProtoIndustry, December 2002

821 Hans Gersbach and Verena Liessem, Financing Democracy, December 2002

822 Costas Hadjiyiannis, Panos Hatzipanayotou, and Michael S. Michael, Optimal Tax Policies with Private-Public Clean-Up, Cross-Border Pollution and Capital Mobility, December 2002

823 François Ortalo-Magné and Sven Rady, Homeownership: Low Household Mobility, Volatile Housing Prices, High Income Dispersion, December 2002

824 Syed M. Ahsan and Panagiotis Tsigaris, Measuring the Social Discount Rate under Uncertainty: A Methodology and Application, December 2002 